\title{
Computer Simulation in Predicting Biochemical Processes and Energy Balance at WWTPs
}

\author{
Jakub Drewnowski ${ }^{1,}{ }^{*}$, Ewa Zaborowska ${ }^{1}$, and Carmen Hernandez De Vega ${ }^{2}$ \\ ${ }^{1}$ Gdansk University of Technology, Faculty of Civil and Environmental Engineering, ul. \\ Narutowicza 11/12, 80-233 Gdansk, POLAND \\ ${ }^{2}$ Polytechnic University of Valencia, School of Civil Engineering, Dept. of Hydraulic Engineering \\ and Environment, Camino de Vera, s/n 46-022 Valencia, SPAIN
}

\begin{abstract}
Nowadays, the use of mathematical models and computer simulation allow analysis of many different technological solutions as well as testing various scenarios in a short time and at low financial budget in order to simulate the scenario under typical conditions for the real system and help to find the best solution in design or operation process. The aim of the study was to evaluate different concepts of biochemical processes and energy balance modelling using a simulation platform GPS-x and a comprehensive model Mantis2. The paper presents the example of calibration and validation processes in the biological reactor as well as scenarios showing an influence of operational parameters on the WWTP energy balance. The results of batch tests and full-scale campaign obtained in the former work were used to predict biochemical and operational parameters in a newly developed plant model. The model was extended with sludge treatment devices, including anaerobic digester. Primary sludge removal efficiency was found as a significant factor determining biogas production and further renewable energy production in cogeneration. Water and wastewater utilities, which run and control WWTP, are interested in optimizing the process in order to save environment, their budget and decrease the pollutant emissions to water and air. In this context, computer simulation can be the easiest and very useful tool to improve the efficiency without interfering in the actual process performance.
\end{abstract}

\section{Introduction}

Mathematical modelling becomes an integral part of the design and operation of water treatment systems, especially with activated sludge (AS) systems [1]. The use of mathematical models and computer simulation allow analysis of many different technological solutions as well as testing various scenarios in a short time and at low financial budget in order to simulate the scenario under typical conditions for the real system and help to find the best solution in design or operation process [2]. Nowadays, a lot of mathematical models, which describe a wastewater treatment plant (WWTP) in different

*Corresponding author: jdrewnow@pg.gda.pl 
ways with good results, had been developed. The biochemical mathematical models called Activated Sludge Model (ASM), which is one of the simplest, describe the conversion of organic compounds, phosphorous and nitrogen. More complex models (such as Mantis2) developed in last years integrate ASM with anaerobic digestion processes, precipitation and/or anammox.

Computer simulation has become a helpful tool in analysis of wastewater treatment systems performance and effectiveness. Using advanced program it is possible to create a mathematical model of a real WWTP, run a simulation and subsequently interpret results under various conclusions. However, the most important to get a successful model is the organization. Firstly, the laboratory tests, full-scale measurements and calculations should be carried out in order to better integrate computer model to the conditions prevailing in the local parameters of each individual parts of WWTP. Secondly, the development of a computer models require a detailed analysis of the whole technological system and taking into account the specific variables to each modelled device/object. The proper estimation of these parameters in model has strong influence on the results of mathematical modelling and computer simulation as well as it consumes a lot of time. Furthermore, the quality of the calibration depends on the objectives of the study which defined the accuracy of the model calibration parameters. For that reason, this step is the hardest and one of the most important of this study.

Water and wastewater utilities, which run and control WWTP, are interested in optimizing the process in order to save environment, their budget and decrease the pollutant emissions to water and air. In this context, computer simulation can be the easiest and very useful tool to improve the efficiency without interfering in the actual process performance. The aim of this study was to evaluate different concepts of the biochemical processes and energy balance modelling using a comprehensive models Mantis2. For this purpose, the sample layout of a WWTP was modelled in a computer program GPS-x ver. 6.4 (Hydromantis, Canada), which was submitted to dynamic simulation.

\section{Material and methods}

\subsection{Study site}

This study was based on archives date from real "Wschód" WWTP (presented earlier by Swinarski et al. [3]) as a base-point for newly developed "virtual" plant layout, extended in the range of sewage sludge treatment with the following device:

- primary sludge thickener,

- waste activated sludge dewatering,

- anaerobic digester,

- $\quad$ digested sludge dewatering (centrifuges).

The schematic layout of plant was created in GPS-x and is presented in Figure 1. Additional information about wastewater treatment process line including activated sludge MUCT system with a single bioreactor compartment (volumes of individual compartments, average DO concentrations in the aerobic zone) are listed in Table 1 as well as characteristics of the average operating conditions at "Wschód" WWTP for computer simulation study can be found in Table 2 . 


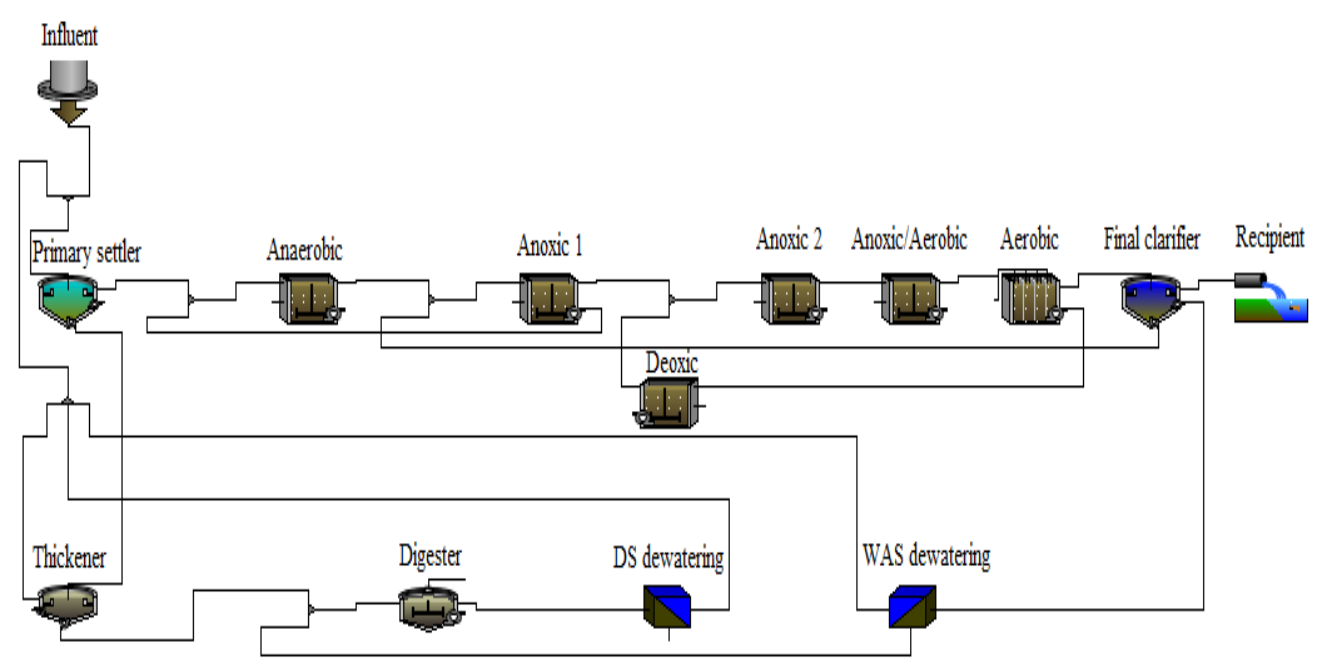

Fig. 1. A schematic layout of the MUCT bioreactor extended in the range of wastewater sludge treatment created in the GPS-x simulator.

The "Wschód" WWTP is located in north of Poland and it is serving a population of Gdansk and adjusting communities (altogether approx. 550,000 inhabitants in 2008), being one of the largest facilities in the Baltic Sea. The virtual plant layout, in which this study is based on, was modified as the following structure. The process wastewater treatment line start with a primary settler followed by a MUCT (Modified University of Cape Town) bioreactor with an additional deoxic zone in the internal recirculation line from the aerobic zone to the anoxic zone and a final clarifier. On the one hand, the sludge produced in the primary settler is carried to the thickener and on the other hand, the sludge produced in the final clarifier is carried to the dewatering process. Afterwards, the thickened sludge from the primary and final clarifiers is mixed and conducted to the digester in which the digestion process will be done in order to produce biogas. Finally, the digested sludge is dewatering in order to get a suitable mud for other possible uses. The water which was separated in the thickened and dewatering processes is carried to header plant with the aim of clean it and do not have any discharge of dirty water. The feedstock for fermentation is a mixture of thickened primary sludge approx. 4\% TSS (Total Suspended Solids) and thickened waste activated sludge (6\% TSS). Reject water from raw and digested sludge dewatering processes is recirculated to the head of wastewater train. 


\begin{tabular}{|c|c|c|c|c|}
\hline 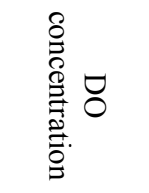 & 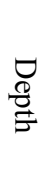 & 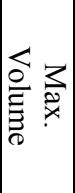 & 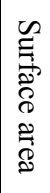 & 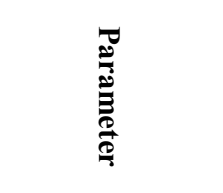 \\
\hline $\begin{array}{l}\text { og } \\
\text { N } \\
\mathbf{B}_{\omega}\end{array}$ & $\Xi$ & $B_{\omega}$ & $B_{N}$ & $\stackrel{\text { S. }}{\text {. }}$ \\
\hline ' & $w_{n}$ & ' & \& & Primary settler \\
\hline ' & $A$ & 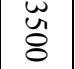 & 1 & Anaerobic \\
\hline ' & $\triangle$ & 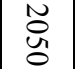 & ' & Anoxic 1 \\
\hline ' & $\Delta$ & $\begin{array}{l}\mathscr{w}_{0} \\
\text { w }\end{array}$ & ' & Anoxic 2 \\
\hline ' & $\triangle$ & $\begin{array}{l}w \\
0 \\
0 \\
0\end{array}$ & ' & $\begin{array}{l}\text { Anoxic / } \\
\text { Aerobic }\end{array}$ \\
\hline $2.93 / 2.25$ & $\triangle$ & $\begin{array}{l}\overrightarrow{0} \\
\text { ஜ্ }\end{array}$ & ' & Aerobic 1/2 \\
\hline $1.66 / 1.21$ & $\triangle$ & $\begin{array}{l}\overrightarrow{0} \\
\text { Ui }\end{array}$ & 1 & Aerobic 3/4 \\
\hline $0.066 / 0.60$ & 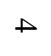 & $\begin{array}{l}\overrightarrow{0} \\
\text { Uĭ }\end{array}$ & 1 & Aerobic 5/6 \\
\hline 1 & $\Delta$ & $\begin{array}{l}\overrightarrow{\tilde{O}} \\
\text { Ond }\end{array}$ & 1 & Deoxic \\
\hline ' & $\omega$ & ' & N & Final clarifier \\
\hline 1 & ' & 岁 & 1 & Digester \\
\hline
\end{tabular}




\subsection{Extracting experimental data}

Laboratory batch test (e.g. nitrogen utilization rate - NUR, P release rate and anoxic/aerobic P utilization rate - PRR and anoxic/aerobic PUR, oxygen/ammonia utilization rate - OUR/AUR) with the process biomass and settled wastewater were carried out in a specially designed and constructed experimental set-up consisting of two parallel batch reactors (max. volume of $4.0 \mathrm{dm} 3$ ), control system and computer. This batch experiments results were obtained by Drewnowski and Makinia [4] at a large (600,000 PE) BNR "Wschód" WWTP in Gdansk (Poland) provided the experimental database for comparison of the model predictions as well as additional 96-hour measurement campaign in the full-scale MUCT bioreactor at this plant presented earlier by Swinarski et al. [3] was integrated to calibration/validation process. During that time only full-scale MUCT bioreactor was simulated using base model ASM2d. This study was set as a extension to evaluate different concepts of the biochemical processes and energy balance modes using a comprehensive model Mantis2 in order to developed procedure of the whole "virtual" plant layout as a base point and test of complex model for practical use in full-scale object.

Table 2. Characteristics of the average operating conditions from "Wschód" WWTP as a base point for "virtual" plant layout simulation study in GPS-x.

\begin{tabular}{|c|c|c|}
\hline Parameter & Unit & Average value in summer 2008 \\
\hline \multicolumn{3}{|c|}{ Concentrations in settled wastewater: } \\
\hline COD & $\mathrm{gCOD} / \mathrm{m}^{3}$ & 695 \\
\hline $\mathrm{BOD}_{5}$ & $\mathrm{gBOD} / \mathrm{m}^{3}$ & 357 \\
\hline $\mathrm{N}_{\text {tot. }}$ & $\mathrm{gN} / \mathrm{m}^{3}$ & 65.9 \\
\hline${\mathrm{N}-\mathrm{NH}_{4}^{+}}^{+}$ & $\mathrm{gN} / \mathrm{m}^{3}$ & 56.1 \\
\hline $\mathrm{P}_{\text {tot. }}$ & $\mathrm{gP} / \mathrm{m}^{3}$ & 50.9 \\
\hline $\mathrm{P}-\mathrm{PO}_{4}^{-}$ & $\mathrm{gP} / \mathrm{m}^{3}$ & 45.6 \\
\hline \multicolumn{3}{|c|}{ Concentrations in secondary effluent: } \\
\hline COD & $\mathrm{gCOD} / \mathrm{m}^{3}$ & 42.1 \\
\hline "Soluble" COD & $\mathrm{gCOD} / \mathrm{m}^{3}$ & 34.5 \\
\hline $\mathrm{N}_{\text {tot. }}$ & $\mathrm{gN} / \mathrm{m}^{3}$ & 10.3 \\
\hline $\mathrm{N}-\mathrm{NH}_{4}^{+}$ & $\mathrm{gN} / \mathrm{m}^{3}$ & 0.135 \\
\hline $\mathrm{N}^{-\mathrm{NO}_{3}^{-}}$ & $\mathrm{gN} / \mathrm{m}^{3}$ & 7.55 \\
\hline $\mathrm{P}_{\text {tot. }}$ & $\mathrm{gP} / \mathrm{m}^{3}$ & 2.53 \\
\hline $\mathrm{P}-\mathrm{PO}_{4}^{-}$ & $\mathrm{gP} / \mathrm{m}^{3}$ & 0.812 \\
\hline \multicolumn{3}{|c|}{ Operating parameters: } \\
\hline $\mathrm{Q}_{\mathrm{INF}}$ & $\mathrm{m}^{3} / \mathrm{d}$ & 21568 \\
\hline $\mathrm{Q}_{\mathrm{MLR1}}$ (anox 1 - anaer) & $\mathrm{m}^{3} / \mathrm{d}$ & 40000 \\
\hline $\mathrm{Q}_{\mathrm{MLR2}}($ aer - anox 2$)$ & $\mathrm{m}^{3} / \mathrm{d}$ & 120000 \\
\hline $\mathrm{Q}_{\mathrm{RAS}}$ & $\mathrm{m}^{3} / \mathrm{d}$ & 20110 \\
\hline Process temperature & ${ }^{\circ} \mathrm{C}$ & 19 \\
\hline Sludge Retention Time & $\mathrm{d}$ & 21.3 \\
\hline \multicolumn{3}{|c|}{ Biomass characteristics: } \\
\hline MLSS & $\mathrm{g} / \mathrm{m}^{3}$ & 5450 \\
\hline MLVSS/MLSS $\left(i_{\mathrm{VT}}\right)$ & - & 0.437 \\
\hline
\end{tabular}




\subsection{Organization of the modelling study procedure}

The comprehensive model Mantis2 incorporates the most commonly observed biological, physical, and chemical processes in WWTPs. This model integrates carbon, nitrogen and phosphorus removal with anaerobic digestion process. The basic structure of the model is based among others on ASM2d and UCTADM1 models. The computer simulations with this model were carried out using the software GPS-x ver. 6.4 simulation platform (Hydromantis, Canada), more can be found in [5]. The model of activated sludge process was calibrated based on results of the batch tests (summer study period) and 96-hour measurement campaign in the full-scale MUCT bioreactor from "Wschód" WWTP in summer 2008. The results of the batch tests with the process biomass and settled wastewater under winter sessions were used to compare model predictions in terms of $\mathrm{NH}_{4}$ $\mathrm{N}, \mathrm{NO}_{3}-\mathrm{N}, \mathrm{PO}_{4}-\mathrm{P}$ behavior and validated the model. This set of the process stoichiometric and the kinetic parameters in ASM2d was used as a base-point of further process calibration in newly developed comprehensive model Mantis2. The Nelder-Mead simplex method was additionally used in order to numerically optimize and final recalibrated/validate parameters of Mantis2 for simulation in newly developed whole "virtual" plant layout in GPS-x as was presented in Table 3.

Table 3. List of the kinetic/stoichiometric parameters in Mantis2 adjusted during model calibration in the GPS-x simulator.

\begin{tabular}{|c|c|c|c|}
\hline Symbol & Unit & $\begin{array}{c}\text { Default } \\
\text { value }\end{array}$ & $\begin{array}{c}\text { Calibrated } \\
\text { value }\end{array}$ \\
\hline \multicolumn{4}{|c|}{ Heterotrophic organisms: } \\
\hline $\begin{array}{c}\text { Aerobic } \\
\text { heterotrophic yield } \\
\text { on soluble substrate }\end{array}$ & $\mathrm{gCOD} / \mathrm{gCOD}$ & 0.666 & 0.625 \\
\hline $\begin{array}{l}\text { Anoxic heterotrophic } \\
\text { yield on soluble } \\
\text { substrate }\end{array}$ & $\mathrm{gCOD} / \mathrm{gCOD}$ & 0.533 & 0.625 \\
\hline $\begin{array}{l}\text { Maximum specific } \\
\text { growth rate on } \\
\text { substrate }\end{array}$ & $1 / \mathrm{d}$ & 3.2 & 6 \\
\hline $\begin{array}{l}\text { Saturation/inivition } \\
\text { coefficient for Sac }\end{array}$ & $\mathrm{g} / \mathrm{COD} / \mathrm{m}^{3}$ & 5 & 4 \\
\hline $\begin{array}{c}\text { Reduction factor for } \\
\text { denitrification on } \\
\text { nitrate-N }\end{array}$ & - & 0.32 & 0.8 \\
\hline $\begin{array}{c}\text { Aerobic } \\
\text { heterotrophic decay } \\
\text { rate }\end{array}$ & $1 / \mathrm{d}$ & 0.62 & 0.4 \\
\hline \multicolumn{4}{|c|}{ Phosphorus Accumulating Organisms: } \\
\hline $\begin{array}{l}\text { Aerobic yield on } \\
\text { PAO growth }\end{array}$ & $\mathrm{gCOD} / \mathrm{gCOD}$ & 0.639 & 0.625 \\
\hline $\begin{array}{l}\text { Anoxic yield on } \\
\text { PAO growth }\end{array}$ & $\mathrm{gCOD} / \mathrm{gCOD}$ & 0.511 & 0.625 \\
\hline PHA storage yield & $\mathrm{gP} / \mathrm{gCOD}$ & 0.4 & 0.5 \\
\hline $\begin{array}{c}\text { Saturation coefficient } \\
\text { of PAO for Sac }\end{array}$ & $\mathrm{gCOD} / \mathrm{m}^{3}$ & 4 & 2 \\
\hline $\begin{array}{l}\text { Rate constant for } \\
\text { storage of poly- } \\
\text { phosphate }\end{array}$ & $\mathrm{gP} / \mathrm{gPAO} / \mathrm{d}$ & 1.5 & 2.5 \\
\hline Aerobic decay & $1 / \mathrm{d}$ & 0.2 & 0.18 \\
\hline
\end{tabular}




\begin{tabular}{|c|c|c|c|}
\hline coefficient for PAO & & & \\
\hline $\begin{array}{c}\text { Anoxic reduction } \\
\text { factor for decay rate }\end{array}$ & - & 0.9 & 0.6 \\
\hline $\begin{array}{c}\text { Poly-P lysis } \\
\text { coefficient }\end{array}$ & $1 / \mathrm{d}$ & 0.2 & 0.1 \\
\hline \multicolumn{4}{|c|}{ Ammonia-oxidizing Organisms: } \\
\hline $\begin{array}{l}\text { Oxygen saturation } \\
\text { for ammonia } \\
\text { oxidizer }\end{array}$ & $\mathrm{gO}_{2} / \mathrm{m}^{3}$ & 0.25 & 0.2 \\
\hline $\begin{array}{l}\text { Ammonia oxidizer } \\
\text { aerobic decay rate }\end{array}$ & $1 / \mathrm{d}$ & 0.17 & 0.12 \\
\hline $\begin{array}{l}\text { Anoxic reduction } \\
\text { factor for decay rate }\end{array}$ & - & 0.5 & 1.5 \\
\hline \multicolumn{4}{|c|}{ Nitrite-oxidizing Organisms: } \\
\hline $\begin{array}{c}\text { Nitrite saturation } \\
\text { coefficient for nitrite } \\
\text { oxidizer }\end{array}$ & $\mathrm{gN} / \mathrm{m}^{3}$ & 0.5 & 0.04 \\
\hline $\begin{array}{l}\text { Oxygen saturation } \\
\text { for nitrite oxidizer }\end{array}$ & $\mathrm{gO}_{2} / \mathrm{m}^{3}$ & 0.68 & 0.1 \\
\hline $\begin{array}{c}\text { Anoxic reduction } \\
\text { factor for decay rate }\end{array}$ & - & 0.5 & 0.3 \\
\hline \multicolumn{4}{|c|}{ Hydrolysis: } \\
\hline $\begin{array}{l}\text { Hydrolysis rate } \\
\text { constant for Xs }\end{array}$ & $1 / \mathrm{d}$ & 3 & 2.5 \\
\hline $\begin{array}{c}\text { Saturation } \\
\text { coefficient for } \\
\text { particulate COD }\end{array}$ & - & 0.1 & 0.2 \\
\hline $\begin{array}{l}\text { Anoxic hydrolysis } \\
\text { reduction factor }\end{array}$ & - & 0.28 & 0.6 \\
\hline $\begin{array}{c}\text { Anaerobic } \\
\text { hydrolysis reduction } \\
\text { factor }\end{array}$ & - & 0.4 & 0.1 \\
\hline
\end{tabular}

The model of AS bioreactor was extended by primary settler and anaerobic digestion chamber in order to develop a complex model of a WWTP. Energy balance followed the simulations of wastewater and solids treatment processes. The operating cost model was used to simulate aeration and pumping energy concurrently to wastewater processes simulation. This study focused on energy consumption by blowers supplying air to a nitrification tank and by pumps for recirculation of activated sludge from a secondary clarifier to the head of the biological reactor. Each of the selected objects was set up to estimate electric power and daily energy consumption. The potential for renewable energy generation was calculated based on simulated biogas production in anaerobic digestion process operated at $37^{\circ} \mathrm{C}$. For a mixture of primary and secondary sludge digestion a default (Mantis 2 model) set of the process parameters was used. The simulations were carried out at steady-state conditions, but dynamic condition was also made in order to calibrate whole "virtual" plant layout for simulation study in GPS-x.

\section{Results and discussion}

The paper presents the example of application of the WWTP model as a tool to optimize plant operation. Sample results and model predictions of batch experiments are presented in Figure $2 \mathrm{a}-\mathrm{b}[4,6]$. Set of the process stoichiometric and kinetic parameters in ASM2d was 
used as a base point of further process calibration in newly developed comprehensive model Mantis2 for simulation study of "virtual" plant layout in GPS-x (Figure 2c). The values of Mantis2 parameters adjusted during dynamic calibration of the full-scale MUCT bioreactor were compared to the default values in Table 3 . With these values, both process rates (PRR, anoxic/aerobic PUR, NUR and AUR) in two-phase batch tests (Figure $2 \mathrm{a}, \mathrm{b}$ ) and behavior of $\mathrm{NH}_{4}-\mathrm{N}, \mathrm{NO}_{3}-\mathrm{N}$ and $\mathrm{PO}_{4}-\mathrm{P}$ concentrations in the full-scale bioreactor (Figure 2c) were matched accurately by the model predictions.

a)

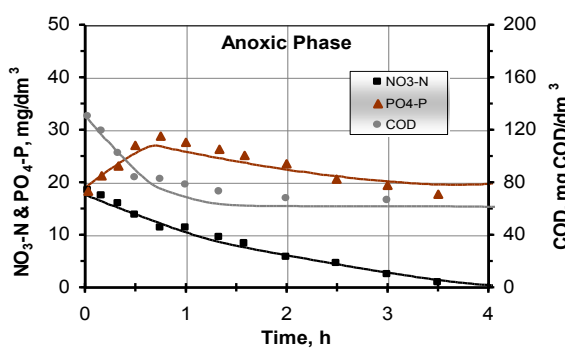

b)

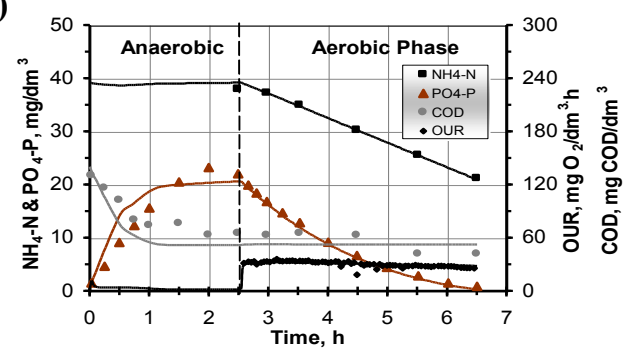

c)

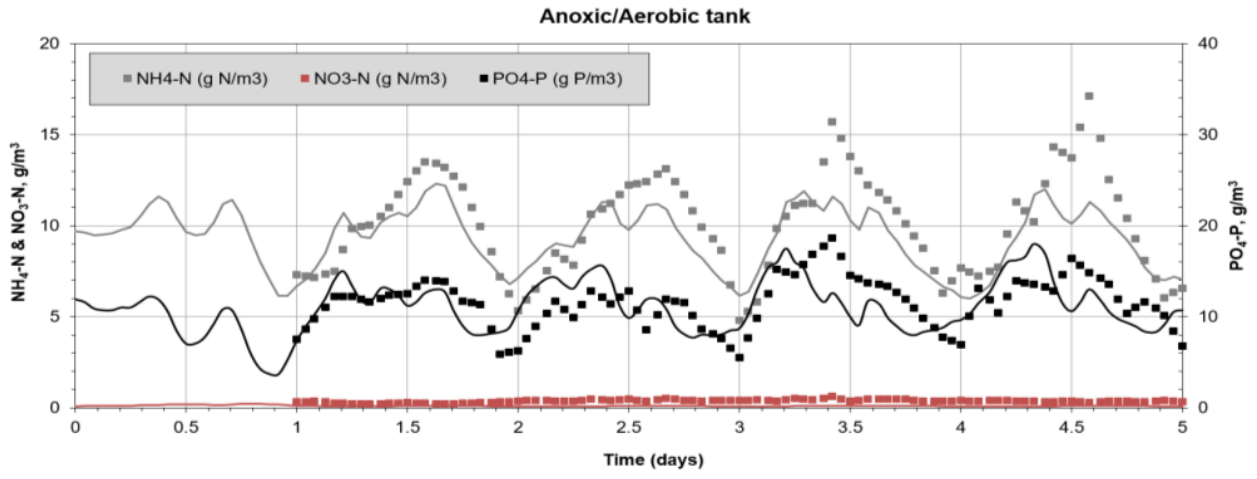

Fig. 2. Sample results of different process rate measurements and model ASM2d/Mantis2 predictions: (a) conventional NUR experiments, (b) PRR/aerobic PUR experiments, (c) anoxic/aerobic zone MUCT bioreactor simulation study of "virtual" plant layout.

During the simulation the changes in the concentration of nitrogen and phosphorus in biological tanks and in the effluent from WWTP was observed. The model predictions were fitted to the measured NURs by adjusting two parameters (based on selected kinetic ASM2d coefficients): the maximum growth rate of heterotrophs $\left(\mu_{\mathrm{H}}\right)$ and hydrolysis rate constant $\left(\mathrm{k}_{\mathrm{h}}\right)$ (Figure 2a). In the NURs during anoxic P uptake, no further modifications were needed to calibrate the NUR in the anoxic phase of the PRR/anoxic PUR test (not shown). The PRR and PUR tests were calibrated with the parameters: the rate constant for storage of PHA ( $\left.\mathrm{q}_{\mathrm{PHA}}\right)$, saturation coefficient for PAOs with respect to $\mathrm{S}_{\mathrm{A}}\left(\mathrm{K}_{\mathrm{SA}, \mathrm{PAO}}\right)$, saturation coefficient for PAOs with respect to polyphosphate $\left(\mathrm{K}_{\mathrm{PP}}\right)$, anaerobic hydrolysis reduction factor $\left(\eta_{\mathrm{fe}}\right)$ and saturation coefficient for particulate COD $\left(\mathrm{K}_{\mathrm{X}}\right)$. The nitrification process based on the measured data from PRR and aerobic PUR batch tests was calibrated with kinetic parameters, including the maximum growth rate of autotrophs $\left(\mu_{\mathrm{A}}\right)$ and the $\mathrm{NH}_{4}-\mathrm{N}$ saturation coefficient $\left(\mathrm{K}_{\mathrm{NH} 4, \mathrm{~A}}\right)$ (Figure $2 \mathrm{~b}$ ). The process calibration in newly developed comprehensive model Mantis2 for simulation study of "virtual" plant layout with the full-scale MUCT bioreactors in GPS-x were started with calibrated results of a series of batch tests with the process biomass (ASM2d) in order to match accurately 
kinetic/stoichiometric parameters. Then previous model of "Wschód" WWTP [3] as a basepoint of further process calibration was used in conjunction with optimization techniques Nelder-Mead simplex to estimate kinetic/stoichiometric parameters in Mantis2 as was shown in Table 3.

The simulations run on the calibrated and validated plant-wide Mantis2 model included scenarios that may influence the WWTP process operation and energy balance. For the purpose of this study, in order to show the possibilities of using simulation software as a tool for predicting a WWTP energy output, the following scenarios were considered:

(1) variation in suspended solids removal efficiency from the primary settler,

(2) variation in returned activated sludge (RAS) flow rate,

(3) variation in dissolved oxygen concentration in the activated sludge reactor nitrification zones.

The first scenario predicted variations in the amount of particulate matter removed form the primary settler. The influence on digestion process and biogas production was observed for three values of primary sludge removal efficiency: $20 \%, 30 \%$ and $40 \%$. The potential for electric energy production by biogas driven combined heat and power plants was calculated for assumed efficiency equal to $35 \%$. The results, presented in Table 4 , show a positive influence of primary sludge digestion on biogas production. The volume of biogas is nearly $25 \%$ higher for suspended solids removal efficiency equal to $40 \%$ in comparison to the reference state. That can definitely improve a WWTP energy balance, increase renewable energy production while decreasing energy purchase. On the other hand a maximum volume of raw sludge removed from a settler is limited by carbon demand in biological step of wastewater treatment and restrictions for effluent quality.

Table 4. Simulated results of digestion process and potential for energy production

\begin{tabular}{|c|c|c|c|c|}
\hline $\begin{array}{c}\text { Suspended } \\
\text { solids removal } \\
\text { efficiency }\end{array}$ & $\begin{array}{c}\text { Biogas } \\
\text { production }\end{array}$ & $\begin{array}{c}\text { Biogas yield per } \\
\text { VSS destroyed }\end{array}$ & $\begin{array}{c}\text { Energy production } \\
\text { in cogeneration }\end{array}$ & $\begin{array}{c}\text { Change in relation } \\
\text { to the reference } \\
\text { state }\end{array}$ \\
\hline$\%$ & $\mathrm{~m}^{3} / \mathrm{d}$ & $\mathrm{m}^{3} / \mathrm{kgVSS}$ & $\mathrm{kWh} / \mathrm{d}$ & $\%$ \\
\hline 20 & 3320 & 1,06 & 7185 & Reference state \\
\hline 30 & 3677 & 1,06 & 7957 & +8.7 \\
\hline 40 & 4293 & 1,07 & 9290 & +24.7 \\
\hline
\end{tabular}

The second scenario focuses on returned activated sludge flow rate and its influence on energy consumption for pumping. The results of simulations are presented in Table 5. A higher RAS rate may lead to better effluent quality but simultaneously may result in distinctly higher energy demand for pumping.

Table 5. Simulated values of RAS pumping energy

\begin{tabular}{|c|c|c|c|c|}
\hline \multicolumn{2}{|c|}{ RAS flow rate } & Pumping power & $\begin{array}{c}\text { Pumping energy } \\
\text { required }\end{array}$ & $\begin{array}{c}\text { Change in relation to } \\
\text { the reference state }\end{array}$ \\
\hline $\mathrm{m}^{3} / \mathrm{d}$ & $\%$ & $\mathrm{~kW}$ & $\mathrm{kWh} / \mathrm{d}$ & $\%$ \\
\hline 25000 & 100 & 24 & 584 & Reference state \\
\hline 75000 & 300 & 73 & 1752 & +200 \\
\hline 100000 & 400 & 97 & 2336 & +300 \\
\hline
\end{tabular}


The subject of the third scenario predicted variation in oxygen concentration in aerobic zones of the activated sludge reactor. The reference state in Table 6 represents the assumptions close to the calibration terms. The lower oxygen concentration was still enough to remove ammonia but at decreased demand for blower energy. Both examples confirm a significant role of oxygen control in aeration tanks as energy required for blowers often has a dominant share in WWTPs energy balance.

Table 6. Simulated results of aeration energy demand

\begin{tabular}{|c|c|c|c|c|}
\hline $\begin{array}{c}\text { Oxygen } \\
\text { concentration } \\
\text { in aerobic zones }\end{array}$ & $\begin{array}{c}\text { Total air flow } \\
\text { to aeration } \\
\text { tank }\end{array}$ & $\begin{array}{c}\text { Blower wire } \\
\text { power }\end{array}$ & $\begin{array}{c}\text { Blower energy } \\
\text { required }\end{array}$ & $\begin{array}{c}\text { Change in relation } \\
\text { to the reference } \\
\text { state }\end{array}$ \\
\hline $\mathrm{gO}_{2} / \mathrm{m}^{3}$ & $\mathrm{~m}^{3} / \mathrm{h}$ & $\mathrm{kW}$ & $\mathrm{kWh} / \mathrm{d}$ & $\%$ \\
\hline $1.0-1.5$ & 15420 & 235 & 5640 & -17.5 \\
\hline $2.0-3.0$ & 18690 & 285 & 6840 & Reference state \\
\hline $3.0-4.5$ & 23090 & 352 & 8448 & $+23,5$ \\
\hline
\end{tabular}

The IWA Activated Sludge mathematical models model is accepted as a useful model to describe biological nitrogen and EBPR in a variety of biological nutrient removal process configurations. The ASM models have been proven to be useful tools for evaluating and optimizing the effect of carbon sources for nitrate/nitrite removal, provided that wastewater biodegradability (COD fractions), kinetics and stoichiometric parameters were determined by Onnis-Hayden and $\mathrm{Gu}$ [7]. Using a simplified version of the Activated Sludge Model no. 2d (ASM2d), De Lucas et al. [8] modeled the results of nitrate utilization experiments with various wastewaters domestic and/or agro-food industrial. Subsequently, the denitrification potential of each carbon source and values of the most important kinetic and stoichiometric parameters for the denitrification process were evaluated. Takacs et al. [9] accurately simulated four full-scale wastewater treatment plants (WWTPs) with an expanded BioWin model (Envirosim, Canada) under aerobic conditions. Dold et al. [10] used modeling to design optimal batch tests procedures, and to estimate the maximum specific growth rate of heterotrophs under anoxic conditions. Phillips et al. [11] used a dynamic model to optimize the mixed liquor recycle rate and studied factors that affected nitrogen removal, including the influent wastewater readily biodegradable $\mathrm{COD} / \mathrm{N}$ ratio and acetate addition. The strategies and calculations of the optimum $\mathrm{COD} / \mathrm{N}$ ratios were investigated by FilaliMeknassi et al. [12] (in sequencing batch reactor (SBR)) and Latimer et al. [13] (in continuous flow reactor). In this study not only biological part of WWTP was simulated but more complex newly developed model of whole plant Mantis2 (which is extension of well known ASM) was calibrated/validated, behaviors of real date $\mathrm{NH}_{4}-\mathrm{N}$ and $\mathrm{NO}_{3}-\mathrm{N}$ and $\mathrm{PO}_{4}-\mathrm{P}$ in the anoxic/aerobic tank of full-scale MUCT bioreactor, as a sample results presented Figure 2c, were matched accurately by the model predictions in the GPS-x simulator. Moreover full-scale simulations during the validation process revealed that addition of winter scenario in Mantis2 compensate with the temperature parameters resulting in a similar $\mathrm{NH}_{4}-\mathrm{N}$ and $\mathrm{NO}_{3}-\mathrm{N}$ and $\mathrm{PO}_{4}-\mathrm{P}$ behavior compared to the reference case (data not shown) presented earlier by Swinarski et al. [3].

\section{Conclusions}

Process optimization performed based on biological system physiology is the next level of system operations that are required to maximize the use of existing facilities. One of the 
main reasons that has limited the use of this approach has been the lack of proper tools to simulate the biological processes. In this study the simulation platform GPS-x and Mantis2 model was found as useful tools for this purpose.

During model calibration, kinetic parameters in previous ASM2d as well as new complex Mantis2 model were adjusted until the real date from "Wschód" WWTP match with simulations. With the calibrated ASM2d/Mantis2, the principal process rates (such as NUR, PRR and anoxic/aerobic PUR, OUR/AUR) were accurately predicted in one/two-phase batch tests and for simulation study of "virtual" plant layout with the full-scale MUCT bioreactors in GPS-x. Continual feedback between the model and real-time measurements (e.g. $\mathrm{NH}_{4}-\mathrm{N}$ and $\mathrm{NO}_{3}-\mathrm{N}$ and $\mathrm{PO}_{4}-\mathrm{P}$ behavior) from "Wschód" WWTP were additionally used to confirm initial modeling results. It was shown that a "well" calibrated model within an assessment study could be used to evaluate process capacities, operational changes, upgrades and/or process changes. Therefore, confidence in the model simulations increases with the degree of calibration conducted. Historical periods defining different operating conditions, intensive sampling and other optimization techniques assist in matching the performance of the model to the full-scale facility.

Energy consumption and generation are crucial in determining wastewater treatment plant operating costs. Computer simulations enable to predict energy balance for different treatment strategies simultaneously with biological and chemical processes. The examined scenarios showed the influence of sample operating parameters variations on the WWTP energy performance. Primary sludge removal efficiency was found as a significant factor determining biogas production under mesophilic conditions and the share of renewable energy in the WWTP energy balance. On the other hand energy savings may be found in different facilities with AS aeration systems.

\section{References}

1. W. Gujer. Wat. Sci. Tech., 53 (3), 111-119 (2006).

2. M. Henze, W. Gujer, T. Mino, M. van Loosdrecht. (London, IWA Publishing, 2002).

3. M. Swinarski, J. Mąkinia, K. Czerwionka, M. Chrzanowska, J. Drewnowski. Water Environment Research, 84 (8), 646-655 (2012).

4. J. Drewnowski, J. Makinia. IJEST 11, 7, 1973-1988 (2014).

5. GPS-X 6.4. User's guide and technical reference. Hydromantis Environmental Software Solutions, Inc. Hamilton (2014)

6. J. Drewnowski, J. Makinia. Wat. Sci. Tech. 67, 9, 2067-2074 (2013).

7. A. Onnis-Hayden, A.Z. Gu. Comparison of Organic Sources for Denitrification: Biodegradability, Denitrification Rates, Kinetic Constants and Practical Implication for Their Application in WWTPs. Proc. the 81st Annual WEF Technical Exhibition and Conference, Water Environment Federation: Alexandria, Virginia, 253 (2008).

8. A. De Lucas, L. Rodríguez, J. Villasenor, F.J. Fernandez. Water Res., 39, 3715 (2005)

9. I. Takacs, M. O’Shaugnessy, S. Murthy, K. Brian, N. Shirodkar, D. Katehis. Design of Denitrification Systems Using Methanol. Proc. the WEF-IWA Specialized Conference "Nutrient Removal 2007: State of the Art. Water Environment Federation, Alexandria, Virginia, 218 (2007).

10. P. Dold, I. Takacs, Y. Mokhayeri, A. Nichols, J. Hinojosa, R. Riffat, W. Bailey, S. Murthy. Denitrification with Carbon Addition - Kinetic Considerations. Proc. the 
WEF-IWA Specialized Conference "Nutrient Removal 2007: State of the Art", Water Environment Federation, Alexandria, Virginia, 218 (2007)

11. H.M. Phillips, J.L. Barnard, C. de Barbadillo, A.R. Shaw, M.T. Steichen, C. WallisLage. Denitrification Rates: Sampling, Modelling and Design Consideration. Proc. the WEF Specialty Conference "Nutrient Removal 2009. Sustainable Treatment Solutions, Water Environment Federation: Alexandria, Virginia, 252 (2009).

12. Y. Filali-Meknassi, M. Auriol, R.D. Tyagi, Y. Comeau, R.Y. Surampall. Environ. Technol., 26, 1081 (2005)

13. R. Latimer, P. Pitt, A. van Niekerk, T. Bruton, S. Dailey, J. Grandstaff, K. Selock. Secondary. Impacts of Supplemental Carbon Addition to BBNR/ENR Treatment Process. Proc. the WEF Specialty Conference "Nutrient Removal 2009. Sustainable Treatment Solutions. Water Environment Federation, Alexandria, Virginia, 849 (2009). 